Oldrich Trenz,

Management Department, Mendel University in Brno,

Brno, Czech Republic

Oldrich Faldik,

Management Department, Mendel University in Brno,

Brno, Czech Republic

Jan Kolomaznik, Management Department, Mendel University in Brno,

Brno, Czech Republic

Patrik Vanek, Management Department, Mendel University in Brno, Brno, Czech Republic

\title{
THE FUTURE OF INVESTING - SUSTAINABLE AND RESPONSIBLE INVESTING
}

The objective of this paper has been the comparison of the selected sustainable and responsible funds in the aspect of positive and negative selection, and also the identification of attitudes of the selected millennials to SRI investing (focusing on environmental, social and governance factors). The approaches to define the methods of selecting investment instruments were analysed and systematized by the authors. The systematized scientific literature allowed to establish that sustainable investing, focusing on environmental, social and governance factors (ESG), addresses not only healthy corporate behaviour, but often keeps the capital safe. Selected funds from the Barron's Magazine and the data from the Bloomberg's ESG Data Service have been used as the source data. It has been established from the available screened data that there are two funds focusing on positive selection in the environmental, social and governance areas. None of these funds is focused explicitly on negative selection only. In the ESG areas, positive selection and/or combination of positive and negative selection has its firm place. Negative choice, however, is applied predominantly within products. With respect to intergenerational differences in the investment approaches, a particular group of millennials, FBE MENDEL students, and their attitudes and views concerning the SRI has been monitored. The research has been performed in the form of an online questionnaire survey, where 96 bachelor-degree students have been engaged, 68 women and 28 men. The following nationalities are included among the respondents: Czech (69), Slovak (21), Russian (3), Ukrainian (1), Belarusian (1) and Kazakh (1). It has been established that the expected return would still prevail over sustainability and social responsibility in case of their own selection of the investment instrument, however, if the SRI investment option is offered, for example, by an investment adviser, the majority of the respondents would be willing to use this investment instrument even at the expense of a lower return.

Keywords: SRI, sustainability, responsibility, investing. 
Introduction. The idea of socially responsible corporate management is not exactly new. For example, back in the eighteenth century, members of some churches refused to invest into companies whose activities had a somewhat controversial impact on the society ( 3 Greatest Myths about Socially Responsible Investing, 2017). Furthermore, the idea of socially responsible investing was highlighted, for example, after the Civil War in the United States, when the society was looking for new ways to change the system, which was unable to provide enough assistance to those in need in the way other than through charity. The socially responsible principles were promoted by such personalities as Andrew Carnegie and John D. Rockefeller (Socially Responsible Investing Gains Popularity, 2017). However, socially responsible investing itself appears on the US market and has been developing actively since the 1970s of the last century. Environment, oil processing and wastes from nuclear power plants were the main topics of that time.

In the 1980s, socially responsible funds were created in the US, such as the Calvert Social Investment Fund Balanced Portfolio and the Parnassus Fund (Donovan, 2018). Both positive and negative selection were already in use for portfolio formation. This selection excluded the companies focused on weapons, tobacco, spirits or gambling, but also more topical issues were highlighted, such as nuclear energy, environmental pollution and relations with employees. At that time, development of this market has also commenced in the United Kingdom of Great Britain and Northern Ireland. In the 1990s, expansion to other Western European countries took place. After the year 2000, socially responsible investing has reached Asian markets.

Interest in responsible investing has been rising steadily and in 2016 the European market of responsible investment funds reached almost US $\$ 476$ billion of the managed assets, nearly double the value as compared with 2010 (Česká sporitelna / the Czech Savings Bank offers, being the first company on the market, the option of pension savings into the Ethical Fund, 2018). The financial means invested into RI (responsible investing) in the US more than doubled in the period of 2012-2016, reaching the level of US $\$ 8.72$ trillion (O'Brian et al., 2017).

Within Europe, the growing number of pension funds contributes to increasing interest in SRI, for which long-term sustainability aspects of corporations are quite material. In some EU Member States, this area is even covered by the acts requesting pension funds to disclose the information how they consider environmental, ethical and social criteria in their investment decisions (Franc et al., 2006).

Large financial corporations in Europe, such as British Aviva, Robeco and SNS REAAL from the Netherlands or French Société Générale, have committed to integrate responsible investing among their activities. The United Nations (UN) have also contributed to development of the market by publishing the "UN Principles for Responsible Investment", which focus on the process of incorporating the social responsibility factor into the investment process (Bublová 2016). The SRI support by the organizations such as the UN, the Global Reporting Initiative (GRI), the Carbon Disclosure Project (CDP), the Sustainability Accounting Standards Board (SASB), and development of the SRI market in Europe and in the US has resulted in the fact that more than $20 \%$ of the global assets (based on estimates of Eurosif and US SIF) are now managed in a sustainable and responsible manner (Clark et al., 2015).

According to Donovan (2018), we are now living in the SRI 2.0 period, which is focused mainly on impacted investment and extension of the general awareness of responsible investing. According to Credit Suisse Millennials, the next generation of investors, have a clear vision when it comes to investments. They want to make and see impact. It is estimated that in the next few decades, the global population under the age of 30 will inherit over USD 40 trillion. A major factor that unites this generation and differentiates them from previous generations is a sense of global connectivity combined with a feeling of collective responsibility for the well-being of the world. In terms of investments, this distinct millennial philosophy means that they do not just care about financial returns. Millennials want to see what impact their investments have and how they can do good for society or the environment. (Credit Suisse: Impact 
Investing: Building Bridges across Generations, 2018)

Comparison of the selected sustainable and responsible funds, based on search of the available information, from the aspect of positive and negative selection, and identification of attitudes of the millennials - future prospective investors - to the investments, is the very objective of this paper.

Literature Review. SRI versus non-SRI investing. Sustainable and responsible investing (SRI) is an investment policy that adds a third dimension to the risk to investment return ratio, namely the social responsibility. The investment decision-making is based primarily on the risk-benefit comparison; SRI being no exception. Although the study by Professor of Corporate Finance at Tilburg University, Luc Renneboog, Finance Professor at Tias Nimbas Business School, Jenk ter Horst, and Professor of Finance at Warwick Business School, Chendi Zhang, published in 2008 in the Journal of Banking \& Finance, comes to the conclusion that investors within SRI are willing to accept lower returns in exchange for the socially responsible investment factor (What You Need To Think About to Get Started In Socially Responsible Investing, 2017). This is what the American hedge fund manager, Cliff Asness (Aliapulios, 2018), points out, the former thinks that SRI is a loss matter where the investor pays one part of its profit for investment responsibility.

Founder of the Conscious Capital advisory firm, Derek Tharp, also points out that the people considering socially responsible investing should be prepared to the fact that their contribution to sustainable development might equal to zero. Tharp also clarifies that the socially responsible investing can in many respects be compared to ordinary activities of everyday life. For example, if you sort wastes in good faith, but someone else thwarts your efforts by throwing unsorted wastes into colour-coded containers. (What You Need To Think About to Get Started In Socially Responsible Investing, 2017).

Unequal definition of what belongs under ethical investing and what is out of its scope, is a major drawback of SRI. Parameters of ethical investing are not kept in ledgers, and are therefore very subjective. For example, Volkswagen stock could have been in ethical indices until it has revealed that its promoted focus on environmental protection, low emissions and efficient production was just an outward gloss, while in fact the company has been deceiving the customers and cheating in emissions tests (Aliapulios, 2018).

However, the studies focused on comparison of SRI performance and risk rate agree largely that impact of ESG on investing is non-negative. Investors can thus invest with similar returns and risks, but into the socially responsible companies. For example, $\mathrm{MSCl}$, one of the major indexing companies, has several indices focused on ethical investing. When compared to common indices, they are almost identical (Aliapulios, 2018). Analysis of the Nuveen company of July 2017 shows that no statistically significant difference in return has been found compared to the general market benchmarks, when the most significant SRI stock indices were subject to valuation. In the long run, therefore, there was no performance penalty for socially responsible investing (O'Brian, et al., 2017).

Robert Shiller, Nobel Prize laureate and economist at Yale University, believes in a long-term advantage of ethical conduct, in a good chance to overcome the stock market. Similarly, the ESG focused funds will overcome their non-ESG competitors (Norton \& Kim, 2017). Clark et al. (2015) report that in 2013 Accenture conducted research in 1000 CEOs in 103 countries and 27 industries and has established that $80 \%$ of the surveyed CEOs can see permanent sustainability as a means to gain competitive advantage. Trnková (2004) also states that investing into the socially responsible companies is considered less risky with possible above-average return.

The study, published in the Journal of Sustainable Finance \& Investment (Friede, et al., 2015), dealing with over 2000 empirical works since 1970, has become the most comprehensive overview of academic research regarding on the ESG topic. The authors have established that the majority of studies show a positive relationship between ESG and corporate financial performance. The results show that ESG investing is justified empirically. Roughly $90 \%$ of the studies have reported a non-negative relationship between ESG and between the corporate financial performance. More importantly, a major part of the 
studies show a positive relationship. The study thus highlights positive impact of ESG on the corporate financial performance, which appears stable over time.

This is consistent with research of ESG impact on performance of US corporate investment bonds over the last seven years (Desclée, et al., 2016), which has proved that the portfolios maximizing ESG and controlling even the other risk factors outperformed the market index. This is a low, but stable performance benefit. European companies such as Total, SAP, Allianz, BASF, Vodafone, Novartis, Unilever or Rosche are also the integral part of the ESG index, which, in seven cases in total, had a better performance than the European Equity Index as a whole for the last seven years (Valentik, 2017).

The Domini Social Index, consisting of 400 primarily large capital corporations in the United States, comparable to the S \& P 500, established in 1990, may be another argument in the future that SRI achieves lower returns (profits) than the traditional indices (Donovan, 2018).

The investment manager's experience, capabilities and skills remain the key factor affecting performance, conventional investing alike (Matthews, 2017).

Methodology. Method of selecting investment instruments. In general, there are two types of selection of the investment instruments, namely the negative and the positive one. The first of them, the negative selection, is older in development and excludes specific companies or whole sectors considered inappropriate from the portfolios, e.g. the companies producing alcoholic beverages, gambling or arms industry companies (Socially Responsible Investing Gains Popularity, 2017). For example, Bloomberg Barclays $\mathrm{MSCl}$ uses a negative selection for the already existing indices to eliminate the issuers involved in the activities contradicting the investment policy, values, or social standards. Such industries include, in addition to those already mentioned, the tobacco or nuclear industry and the gambling sector (Desclée et al., 2016). The specific excluded companies are those using child labour, speculating on food prices, producing genetically modified crops, acting unacceptably or controversially (Česká sporitelna / the Czech Savings Bank offers, being the first company on the market, the option of pension savings into the Ethical Fund, 2018). The funds designated as ESG, thought they are only slightly modified originals, e.g. tobacco industry excluded, thus appear as a result of the negative selection (Norton \& Kim, 2017).

Positive selection, on the other hand, is focused directly on the companies committing themselves (through their statutes) to develop their activities in line with the CSR principles, thus contributing voluntarily to building a better environment (Social Responsibility Investing gains in Popularity, 2017). The ESG criteria, environmental, social and administrative components, play a key role here, not only in the statutes and approach, but also in the corporate practice and responsiveness to ESG challenges and issues. The SRI funds evaluate companies for example by their approach to employees, respect for human rights or sustainable business, explains CEO of NN Investment Partners in the Czech Republic, Jan D. Kabelka (Socially Responsible Investing Gain Popularity, 2017).

As part of the positive selection, unlike the negative one, the issuer can operate in a controversial sector, such as mining, in case of proactive management of the risks associated with the sector in question (for example, cleaning actions or social development of the community) exceeding the standard industry practice. (Desclée, et al., 2016) The ESG index also includes, for example, the Total company, the largest European refinery, which has committed itself to reduce emissions by $50 \%$ in the period 2010 to 2020 . By 2015 , emissions have really dropped by $40 \%$. Therefore, ESG is not understood a "green extremism", but a long-term sustainable business (Valentik, 2017). The indices incorporating the ESG criteria are looked for actively by the companies with the best ESG practices within the industry. Some of them include even religious or political principles (Norton \& Kim, 2017).

Sustainable investing, focusing on environmental, social and governance factors (ESG), addresses not only healthy corporate behaviour, but often keeps the capital safe. Analyzes by the companies such as MSCl help the investors to avoid risk companies, which is the case of Equifax (weaker personal data protection contributed to hacker attacks and data leakage), Valeant Pharmaceuticals International 
(investigation concerning price dictation) and Volkswagen (proven fraud in measuring vehicle emissions) (Norton \& Kim, 2017).

For example, all securities acquired in the Ethical Fund of Česká sporitelna have to be valued in terms of ESG, including the state bonds. The clients' finances are thus not valued up by investing into the bonds issued by the states having problems with respect for human rights or disposing of nuclear weapons (Česká sporitelna / the Czech Savings Bank offers, being the first company on the market, the option of pension savings into the Ethical Fund, 2018).

The data concerning suitable companies can either be identified and processed by the investor himself, or the investor can engage the companies specialized directly in ESG criteria analyses. For example, the STOXX Global ESG Leaders stock index uses the underlying documents released by the company Sustainalytics to include the leading global companies in terms of the ESG criteria (Desclée, et al., 2016).

This article provides an overview of the top sustainable mutual funds. Selected funds from the premium financial Barron's Magazine and the data from the Bloomberg's ESG Data Service have been used as the source data. Based on comparison of these two sources, the top SRI funds have been selected and their approaches to portfolio selection in terms of positive and negative selection compared. The source data are available on:

- https://charts.ussif.org/mfpc/

- http://online.wsj.com/public/resources/documents/TopSustainableMutualFunds.pdf

Barron's ranks in total 203 funds of large actively managed companies among the top SRI funds, whilst Bloomberg works with 206 funds of the companies, institutional members of the US SIF Foundation's Center for Sustainable Investment Education. Compliance, i.e. the fund is included in both lists, has been found in 9 funds analyzed in this paper below.

Quantitative research. The research has been conducting between the millennials, namely students of the Faculty of Business and Economics, Mendel University in Brno. Generation Nexters also known as Gen Y or "Millennials" are those people who are born 1980-2000. (Píchová et al.) Millennials may face three major problems in relation to management learning: lack of concentration, lack of engagement, and lack of socialization. (Karakas et. al.) On the other hand they have a new way of thinking including a lot of information gained online and select the information they consider important. This attitude is used in their approach to investing. More and more students think about investing their finances.

Data collection was commenced in February 2018 and will continue for the whole semester, i.e. till the end of May 2018.

The research is performed in the form of an online questionnaire survey, where 96 bachelor degree students have been engaged till now, of which 68 women and 28 men. The second year is represented by 63 students and the third year by 33 students. The youngest respondent is 20 years old and the oldest respondents are 24 years old. More than one half of respondents already have jobs (52\%). The majority of respondents $(64 \%)$ consider their income or income of their family satisfactory, because the household covers all its needs adequately. The following nationalities are included among the respondents: Czech (69), Slovak (21), Russian (3), Ukrainian (1), Belarusian (1) and Kazakh (1).

The following has been investigated: whether or not the respondents have already considered investing their funds; what criteria for investment decision-making are crucial for them; to what extent is it important for them, when making investment decisions, whether or not the instrument, which the money is invested in (fund, etc.), is sustainable and socially responsible; whether or not they are willing to risk more in order to achieve a higher return; whether or not they are willing to sacrifice part of the return if it is an investment in socially responsible instruments.

Empirical results and discussion. Comparison of top SRI funds. The selected nine funds can be broken down into the following categories by the fund type: Equity large cap; All cap; Equity Speciality. 
The following funds belong to the first category - Equity large cap: Brown Advisory Sustainable Growth Fund (BAFWX); Calvert Equity Portfolio A (CSIEX); Domini Social Equity Fund (DSEFX); Neuberger Berman Socially Resp. Inv. (NBSRX); Parnassus Core Equity Fund (PRBLX); Sentinel Sustainable Core Opportunities Fund (MYPVX).

The second category - All cap is represented by: Parnassus Fund (PARNX).

The third category - Equity Speciality - covers the following funds: Parnassus Endeavour Fund; TIAACREF Social Choice Equity Institutional.

Overview of these funds and their focus is given in Table 1.

Table 1 shows that from the available scanned data, two funds are focused on positive selection in the environmental, social and governance areas. It is the Brown Advisory Sustainable Growth Fund and the Sentinel Sustainable Core Opportunities Fund. The first fund as above does not screen the product data and the other one is focused on negative selection in this area. None of the funds is focused strictly on negative selection. In the ESG areas, we are speaking mainly about positive selection and/or combination of positive and negative selection. The Conflict Risk area is the speculative and also the single area where negative selection is applied within ESG. Negative choice, however, is largely applied in the products, mainly all alcohol, defense/weapons, gambling and tobacco. Three cases of positive selection have been recorded in the animal welfare area.

Table 1 - Top SRI funds (based on The Forum for Sustainable and Responsible Investment; Morningstar (2017), Sustainalytics in The Top Sustainable Mutual Funds (2017))

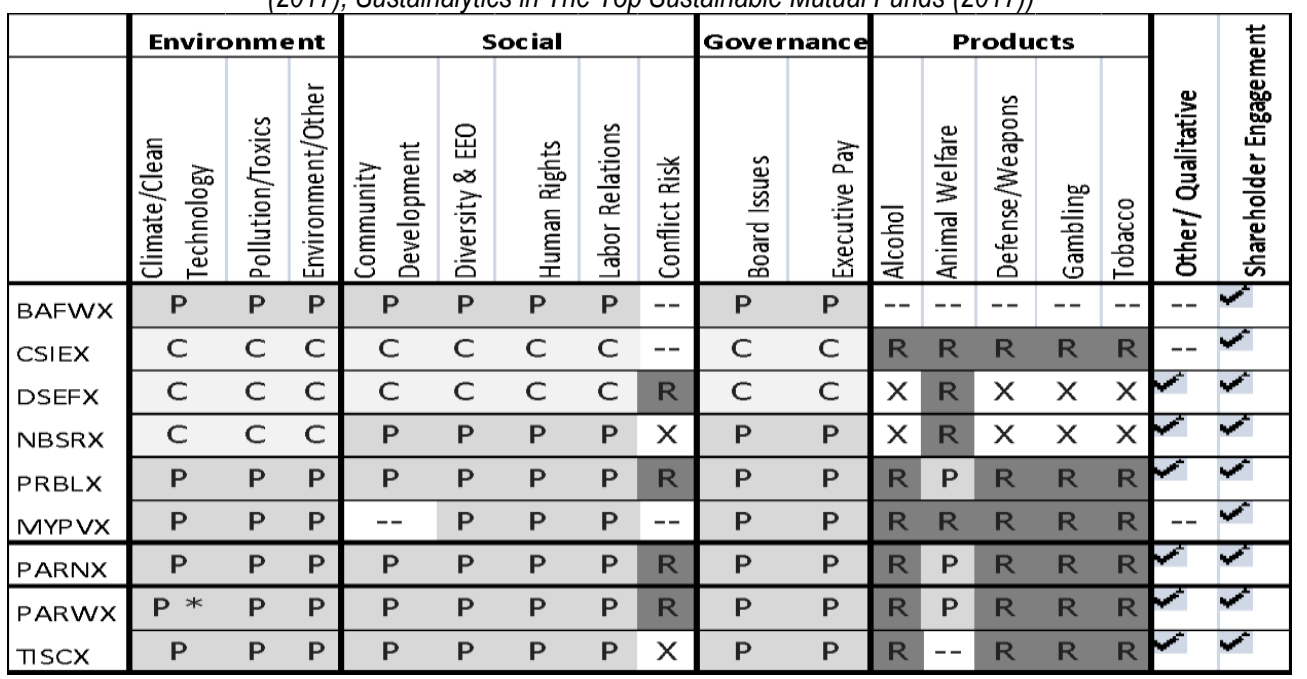

Where: designation (-) means that the fund does not screen data in this area.

$X \quad$ No Investment: Excludes investments engaged in this activity

P Positive Investment: Seeks investments with positive impact in this area

R Restricted/exclusionary Investment:Seeks to avoid poorer performers in this area

C Combination of Positive and Restricted/exclusionary strategies

Attitude of millennials to investing. Results of our research prove that the rising generation of millennials already considers possibilities of investing their funds $(71 \%)$. These facts can also be complemented and supported by outcomes of the research also conducted at the Faculty of Business and Economics, Mendel University in Brno, where it has been established that these students "would like to live in a society that is more focused on the highest economic performance, technical advantages, the

http://mmi.fem.sumdu.edu.ua/en 
decisions are taken by experts, life is driven by rules (not by freedom) and they prefer modernization changes (not the maintenance of traditions). It can be summarized that the majority of students at FBE are technological, modernizing and expert optimists." (Pavlíková, Šmídová, 2017)

Though the criterion of whether or not their funds are invested in socially responsible and sustainable instruments was ranked only among the last ones in investment decision-making (see Table 2), 39\% of respondents consider this criterion very important (2) or rather important (35) when decision making. On the contrary, $36 \%$ of respondents consider this criterion absolutely unimportant (9) or rather unimportant (26). 24 respondents answered this question "I do not know".

Table 2 - Preferences of respondents in investment decision making

\begin{tabular}{|c|c|}
\hline Sequence & Criterion \\
\hline 1 & Expected return \\
\hline 2 & Return to loss ratio \\
\hline 3 & Rate of loss risk \\
\hline 4 & Guaranteed rate of return \\
\hline 5 & $\begin{array}{l}\text { Whether or not the investment is time-limited or there is the option of immediate funds } \\
\text { withdrawal }\end{array}$ \\
\hline 6 & Maximum possibility of fund control and handling ("I want to manage everything by myself") \\
\hline 7 & $\begin{array}{l}\text { Whether or not my funds are invested in the investment instruments that do not affect } \\
\text { society and the environment negatively (tobacco industry, alcohol, etc.) }\end{array}$ \\
\hline 8 & $\begin{array}{l}\text { Whether or not my funds are invested in socially responsible and sustainable instruments } \\
\text { (i.e. in the funds preventing negative impact on society and promoting socially responsible } \\
\text { activities) }\end{array}$ \\
\hline 9 & Services provided by an investment intermediary ("I do not have to worry about anything") \\
\hline
\end{tabular}

In order to achieve a higher return, $48 \%$ of respondents are willing to take a higher risk, whilst $52 \%$ of respondents prefer a lower return with minimized risk. An important finding is that $57 \%$ of respondents are willing to sacrifice part of their return if it is an investment in socially responsible instruments.

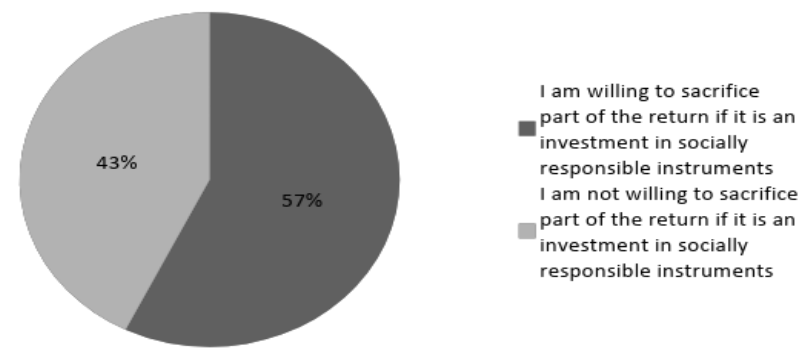

\section{Figure 1 - Respondents' willingness to sacrifice part of their return if it is and investment in socially responsible instruments}

It can therefore be assumed that, in case of selection of one's own investment instrument, the expected return would still prevail over sustainability and social responsibility, however, if the SRI investment option is offered, for example, by an investment adviser, the majority of respondents would be willing to use this investment instrument even at the expense of a lower return.

Conclusion. This paper has addressed the SRI investing. Comparison of the selected sustainable and responsible funds, based on search of the available information, from the aspect of positive and negative selection, was the very objective of this paper. It has been established that from the available 
screened data there are two funds focusing on positive selection in the environmental, social and governance areas. None of these funds is focused explicitly on negative selection only. In the ESG areas, positive selection and/or combination of positive and negative selection has its firm place. The Conflict Risk area is the speculative and also the single area where negative selection is applied within ESG. Negative choice, however, is largely applied in the products. With respect to the intergenerational differences in investment approaches, a particular group of millennials, FBE MENDEL students, and their attitudes and views concerning the SRI has been monitored. It has been established that the expected return would still prevail over sustainability and social responsibility in case of their own selection of the investment instrument, however, if the SRI investment option is offered, for example, by an investment adviser, the majority of respondents would be willing to use this investment instrument even at the expense of a lower return.

Acknowledgement. The authors are thankful to the Grant Agency of Czech Republic (GAČR), project: "Modelling and simulation of sustainable investment decision-making, CEP ID GA17-23448S.

3 největši mýty o sociálně odpovědném investování, 2017 [online]. Investiční web s.r.o., 20/06/2017 [cit. 07/02/2018]. Available at: http://www.investicniweb.cz/3-nejvetsi-myty-o-socialne-odpovednem-investovani/.

Aliapulios, J. (2018). Ohleduplné fondy jsou marketingový tah, ríká investor Jan Pravda, [online]. Economia, a.s., 09/01/2018 [cit. 08/02/2018]. Available at: https://archiv.ihned.cz/c1-66011290-ohleduplne-fondy-jsou-marketingovy-tah-rika-investor-janpravda.

Bublová, A. (2016). Společensky odpovědné investování [online]. Brno, 2016. Diplomová práce. Masarykova univerzita, Ekonomicko-správní fakulta, Katedra financí, 22/06/2016 [cit. 08/02/2018]. Available at: http://narodniportal.cz/wpcontent/uploads/2016/08/Spolecenskyodpovedneinvestovani.pdf.

Clark, G., Feiner, A.; Viehs, M. (2015). From The Stockholder To The Stakeholder, 2015 [online]. Arabesque Partners \& University of [cit. 10/02/2018]. Avford, [vailable https://arabesque.com/research/From_the_stockholder_to_the_stakeholder_web.pdf.

Credit Suisse. Impact Investing: Building Bridges across Generations. 26.1.2018 [online] [cit. 06/02/2018] Available from: https://www.credit-suisse.com/corporate/en/articles/news-and-expertise/impact-investing-building-bridges-across-generations201801.html.

Česká spořitelna nabízí jako první na trhu možnost penzijního spoření do etického fondu (2018) [online]. 16/01/2018 [cit. 06/02/2018] Available at: https://www.bankovnipoplatky.com/ceska-sporitelna-nabizi-jako-prvni-na-trhu-moznost-penzijnihosporeni-do-etickeho-fondu-36264

Desclée, A., Hyman, J., Dynkin, L., Polbennikov, S.. Sustainable investing and bond returns (2016) [online]. Barclays Bank PLC [cit. 07/02/2018] Available at: https://www.investmentbank.barclays.com/content/dam/barclaysmicrosites/ibpublic/documents/ourinsights/esg/barclays-sustainable-investing-and-bond-returns-3.6mb.pdf.

Donovan, W. A Short History of Socially Responsible Investing, (2018) [online]. The Balance, 07/02/2018 [cit. 13/02/2018]. Available at: https://www.thebalance.com/a-short-history-of-socially-responsible-investing-3025578.

Franc, P., Nezhyba, J., Heydenreich, C. (2006). Když se bere společenská odpovednost vážně [online]. Ekologický právní servis, Brno [cit. 05/02/2018]. Available at: http://frankbold.org/sites/defaultffiles/publikace/kdyz_se_bere_csr_vazne.pdf.

Friede, G., Busch, T., Bassen, A. (2015) ESG and financial performance: aggregated evidence from more than 2000 empirical studies [online]. Journal of Sustainable Finance \& Investment, 5:4, 210-233, [cit. 06/02/2018].

Karakas, F., Manisaligil, A., Sarigollu, E. (2015). Management learning at the speed of life: Designing reflective, creative, and collaborative spaces for millenials. International Journal of Management Education, Volume 13, Issue 3, p. 237-248, DOI: 10.1016/j.jime.2015.07.001.

Matthews, J., Leary, K., Mudaliar, A., Pineiro, A., Dithrich, H. (2017). The Financial Performance Of Real Assets Impact Investments, 2017 [online]. Cambridge Associates LLC, [cit. 07/02/2018]. Available at: https://thegiin.org/assets/The $\% 20$ Financial\%20Performance $\% 20$ of $\% 20$ Real\%20Assets $\% 20$ Impact $\% 20$ Investments_webfile.pdf.

Morningstar, Sustainalytics in The Top Sustainable Mutual Funds. [online] 30/9/2017. [cit. 07/02/2018], Available at: http://online.wsj.com/public/resources/documents/TopSustainableMutualFunds.pdf.

Norton, L., Kim, C. (2017) The Top-Performing Sustainable Funds [online]. Dow Jones \& Company, Inc, 07.10.2017 [cit. 05/02/2018]. Available at: https://www.barrons.com/articles/the-top-performing-sustainable-funds-1507350787.

O čem musite přemýšlet, než začnete se sociálně odpovědným investováním (2017) [online]. Investični web s.r.o., 26.10.2017 [cit. 07.02.2018]. Dostupné z: http://www.investicniweb.cz/o-cem-musite-premyslet-nez-zacnete-se-socialne-odpovednyminvestovanim/.

O'Brian, A., Liao, L., Campagna, J. (2017). Responsible Investing: Delivering competitive performance [online]. Nuveen Investments, [cit. 09/02/2018]. Available at: https://www.tiaa.org/public/pdf/ri_delivering_competitive_performance.pdf. 
Pavlíková, E. \& Šmídová, M. (2018). Do we know the attitudes of future managers and other professions? Enterprise and Competitive Environment: Conference Proceedings. Brno: Mendelova univerzita v Brně, p. 3--12. ISBN 978-80-7509-499-5. Available at: https://ece.pefka.mendelu.cz/sites/defaultffiles/imce/ECE2017_fin.pdf.

Píchová, K., Janiš, V., Drínovská, E., Lisický, A. (2016). Generation Y: attitudes to future employment. PEFnet. Brno: Mendel University in Brno, p. 43. ISBN 978-80-7509-445-2.

Společensky odpovědné investování získává na popularitě (2017) [online]. Investiční web s.r.o., 09/08/2017 [cit. 07/02/2018] Available at: http://www.investicniweb.cz/spolecensky-odpovedne-investovani-ziskava-na-popularite/.

The Forum for Sustainable and Responsible Investment. [online] 31/1/2018. [cit. 07/02/2018], Available at: https://charts.ussif.org/mfpc/.

Trnková, J. (2004) Společenská odpovědnost firem: kompletní prưvodce tématem \& záveryy z pruizkumu v CR [online]. Business Leaders Forum [cit. 04/02/2018]. Available at: http://www.neziskovky.cz/data/yyzkum_CSR_BLF_2004txt8529.pdf.

Valentík, M. (2017) Sociálně odpovědné investování - utopie, ekoterorismus, nebo smysluplné zhodnocení? [online]. CN Invest a.s., 09/08/2017 [cit. 08/02/2018]. Available at: http://www.e15.cz/finexpert/investujeme/socialne-odpovedne-investovani-utopieekoterorismus-nebo-smysluplne-zhodnoceni-1335775.

C. Форманкова, Університет Менделя в Брно (Брно, Чехія);

О. Тренц, Університет Менделя в Брно (Брно, Чехія);

о. Фальдік, Університет Менделя в Брно (Брно, Чехія);

Я. Коломазнік, Університет Менделя в Брно (Брно, Чехія);

П. Ванек, Університет Менделя в Брно (Брно, Чехія).

Майбутнє інвестування: стале й відповідальне інвестування

Метою даного дослідження є порівняльний аналіз функціонування інвестиційних фондів, що діють у відповідності до принципів соціально-відповідального інвестування (SRI), а також визначення ставлення різних поколінь до їх діяльності. Автори проаналізували й систематизували підходи до визначення методів відбору інвестиційних інструментів. Систематизація наукової літератури дозволила встановити, що стале інвестування базується на ESG-nідході, що передбачає системне поєднання екологічних, соціальних і управлінських детермінант. Це сприяє не тільки формуванню більш досконалого корпоративного управління, а й підвищенню безпеки капіталу. Загалом відношення інвестииійних фондів до капіталовкладень в охорону навколишнього середовища, соціальну сфреру та корпоративне управління може бути позитивним, негативним та комбінованим. Позитивне та/або комбінація позитивного і негативного відношення фондів проявляється переважно щодо інвестування у зовнішні проекти (природоохоронні та соціальні), тоді як при прийнятті інвестиційних рішень щодо внутрішньокорпоративного інвестування (нова продуктова лінійка, оновлення технологій тощо), то відношення в переважній більшості випадків трансформується у негативне. В якості вихідних даних в дослідженні були використані інформаційні дані журналу Barron's Magazine та статистичні дані служби даних ESG Bloomberg. На основі емпіричних та теоретичних даних для дослідження обрано два інвестиційні фонди, діяльність яких базується на ESG-nідході. 3 метою оцінки впливу вікового фрактору на ставлення до соціально-відповідального інвестування, було проведено аналіз фокус-групи студентів фокультету бізнесу та економіки (Університет Менделя). Дослідження проводилося в формі онлайн-анкетування, в якому взяли участь 96 студентів бакалаврату ( яких 68 - жінки та 28 чоловіки). До групи респондентів увійшли студенти різних національностей: чехи (69), словаки (21), росіяни (3), україниі (1), білоруси (1) й казахи (1). Було встановлено, що очікуваний дохід (як і раніше) буде превалювати над стійкістю та соціальною відповідальністю в разі їх власного вибору інвестиційного інструменту. Однак, при цьому встановлено, що, якщо варіант соціально-відповідального інвестування пропонується, наприклад, інвестиційним консультантом, більшість респондентів були б готові використовувати цей інвестиційний інструмент навіть за рахунок більш низького прибутку.

Ключові слова: соціально-відповідальне інвестування, стійкість, відповідальність, інвестування. 